\title{
CASSAVA PRODUCTS VALUE CHAIN ANALYSIS AMONG ACTORS' PROCESSORS UNDER TRADITIONAL AND IMPROVED TECHNOLOGIES IN NASARAWA STATE, NIGERIA
}

\author{
Oladele Ayoola Olugbenga \\ Department of Agricultural Extension and Management, Federal College of Forestry \\ Mechanization, Forestry Research Institute of Nigeria (FRIN), Kaduna, Nigeria
}

Alabi Olugbenga Omotayo*

Department of Agricultural-Economics, University of Abuja, Gwagwalada-Abuja, Nigeria

\author{
Maharazu Ibrahim \\ Directorate of University Advancement, Kaduna State University (KASU), Kaduna, Nigeria
}

„E-mail: omotayoalabi@yahoo.com

\begin{abstract}
This study examined cassava products value chain analysis among actors' processors under traditional and improved technologies in Nasarawa State, Nigeria. Specifically, the study was designed to achieve the following objectives: determine the socio-economic characteristics of cassava processors, analyze the costs and returns of actors processing cassava into chips and garri, determine the mean rating of traditional and improved technologies utilized by actors, evaluate factors influencing output of cassava processing into chips, and garri by actors, and determine the constraints or problems facing actors or processors in the activities of processing cassava into chips, and garri. The study employed multi-stage sampling design. Total 100 actors' processors engaging in cassava processing activities were sampled and utilized .Primary data were utilized using well-designed, structured questionnaire. The statistical and econometric tools employed were, descriptive statistics, gross margin model, financial analysis, net income analysis, five point Likert scale, Probit Model analysis, and principal component analysis (PCA). The results show that $92 \%$ of actors in cassava processing activities were between 21 to 50 years of age. The mean age of actors was 41 years. About $82 \%$ of actors had formal education. The mean household size was 9 people. Also, $47 \%$ of actors had less than 20 years experiences in cassava processing activities. The calculated net returns for garri enterprise were 42,000 Naira. The net returns for cassava chips enterprise were calculated to be 20,550 Naira. The gross margin ratios for garri and cassava chips were 0.57 and 0.49 respectively. This means that for every one (1) Naira invested in garri and cassava chips enterprises, 57 kobo and 49 kobo covered expenses, taxes, profits, and depreciation for garri and cassava chips enterprises respectively. The major traditional technologies used by actors were: local bag (jute) for bagging cassava products, hand grating for peeling cassava, and calabash bowl used for washing cassava products. The improved or modern technologies used by actors include: mechanical pulverizer, solar drier for drying cassava products, kiln or oven for drying cassava products, motorized grater for grating cassava, and mechanical peeler. The statistical significant variables influencing output of cassava processing by actors include: gender $(P<0.05)$, marital status $(P<0.01)$, experience in cassava processing $(P<0.01)$, level of education $(P$ $<0.01)$, contact with extension agents $(P<0.01)$, and distant to nearby market $(P<0.01)$. The major constrains or problems facing actors in cassava processing activities were; high cost of processing inputs, high cost of transportation, shortage of hired labour, lack of access to credit facilities amongst others. The retained variables explained $98.61 \%$ of the variations included in the model. The study recommends that extension agents should be employed to disseminate research findings on improved or modern processing technologies to actors, also government should formulate policies to stabilize prices for agricultural commodities,
\end{abstract}


actors should also form cooperative organizations to access credit facilities and modern processing equipments.

\section{KEY WORDS}

Cassava Value Chain, Actors, Traditional, Improved Technologies, Nasarawa State, Nigeria.

Cassava (Manihot esculentus) is an important staple, basic food for millions of people in the world. Cassava is occupying number $4^{\text {th }}$ among the major important food crops across the whole world. Cassava comes after maize (grain), wheat (grain), and rice (grain). It is grown majorly in sub-Saharan Africa. Nigeria is observed to be the largest producer of cassava in the world. The quantity of cassava produced in Nigeria in 2018 was about 53.0 million metric tonnes (CBN, 2019). The area used for harvesting of cassava in 2017 was 6.79 million hectares in Nigeria. It was estimated that the average yield of cassava in Nigeria was 87.5 metric tonnes per hectare (FAO, 2019). The major secondary products from cassava processing which has high market and industrial values were; chips, garri, flour or lafun, starch, pellets, adhesives, alcohol. The industries that utilize cassava products include amongst others: livestock, alcohol and or ethanol, textile, food, wood, soft drink, confectionary, pharmaceuticals industries. The casaava products can be of high value tradable both in local and international markets (Knipscheer et al, 2007). Most farmers preferred cassava firstly, it requires low input, secondly, it is tolerance to small amount of rainfall, thirdly, it can survive in poor soils, and fourthly, it can be propagate with ease using the stem called vegetative cuttings. Cassava is observed to be grown in about 105 countries across the whole world, and it is grown in about 24 million hectares of land (CBN, 2019). All various forms of activities that are involved from the start which is called conception through different stages or phases in bringing a product, services to final consumers is called value chain. Value chain involves various activities, producers, transformations of physical products, actors, processors, marketers, transporters, consumers. Utilities were created in different forms, different times, and different places. Processing of cassava is labour intensive, and the fresh tubers are highly perishable in nature. The actors or processors are further faced with challenges of using technology that are poor, they could not access the markets easily, the actors had low productivity, the transport cost is very high, they had poor infrastructures, they utilized traditional methods of processing. Actors do not have efficient machine called dryers. In sub-Saharan Africa, all efforts made to get maximum potentials coming from agriculture including cassava processing would leads to reduction in poverty in the region. There is high demand and high potentials that can be observed in the cassava value chain, there is the demand for cassava flour of high quality in areas like snacks, biscuits, and bread, there is high demand for starch from cassava, cassava based constituents like sugar syrup and sweeteners are in high demand, there is high demand for ethanol or bio-fuel, ethanol can be used for cooking, it can be used to power vehicles, It can be used in industries (CBN, 2019).Bakery and pasta products can use cassava flour as partial replacement. Cassava can be used to feed poultry, pigs and ruminants. Non-food industries which include corrugated cardboard, furniture, paper and or plywood use dextrin as high quality adhesives. Fruit canning and jam industry can also be added to use dextrose. Most sweetening agents involve glucose and dextrose. The cyanogens which are contained in cassava are removed through processing. Processing of cassava in Nigeria are smallscale in nature, the products may not be for commercial purpose and may also not be of high standard for international markets yet, processing methods are inefficient, therefore to address these challenges and improve the standard of cassava processing, a lot of problems or challenges needs to be addressed. Through processing, values are added to cassava, market values are increased through processing, and employment opportunities were created. In sub-Saharan Africa, cassava products were perceived to be both food security crop, and also for raw materials for our industries (Nang'ayo et al, 2005).

Objectives of the Study. The broad objective was to examine the cassava products value chain analysis among actors' processors under traditional and improved technologies in Nasarawa State, Nigeria. Specifically, the study was designed for the following objectives: 
- determine the socio-economic characteristics of cassava processors;

- analyze the costs and returns of activities involving actors processing cassava into chips, and garri;

- determine the mean rating of traditional and improved technologies utilized by actors;

- evaluate factors influencing output of cassava processing into chips, and garri;

- determine the problems or constraints facing actors or cassava processors.

\section{METHODS OF RESEARCH}

The Study Area. The study was conducted in Karu Local Government of Nasarawa State of Nigeria. The local government lies on Latitudes $9^{\circ} 02 \mathrm{~N}$ and $69^{\circ} 0 \mathrm{~N}$, Longitudes $7^{0} 45$ $\mathrm{E}$. The land area mass is about $2,640 \mathrm{~km}$. The population of the Local Government is about 205,477 people following 2006 National population census. The inhabitants of the area were smallholder farmers who major in cassava processing activities. They process the bulk of cassava into garri and chips. In addition the inhabitants also major in farming activities and they grow crops like cassava, yam, sorghum, beans, millet, maize and many others. Apart from farming the inhabitants are traders.

Sampling Techniques and Sample Size. Multi-stage sampling technique was employed in the selections of actors which were cassava processors. First stage involves the selection using random selection ballot-box raffle draw method of two (2) agricultural zones. Second Stage, five (5) districts were randomly selected from each zone using ballot-box raffle draw method. Third stage involves the selection of five (5) communities per district using random selection ballot - box raffle draw method. Fourth final stage, two (2) processing units were selected using random ballot-box raffle draw selection method. Total of one hundred (100) actors who were cassava processors were interviewed.

Method of Data Collection. Primary and secondary sources of data were used. Primary data were employed using well-designed structured questionnaire. Secondary sources were from agricultural articles or journals, bulletins, and data from federal office of statistics. The well-designed and structured questionnaire was subjected to validity and reliability test. The information that were collected using questionnaires involves variables like age, sex, marital status, various technologies employed in cassava processing by actors, costs and income earned, problems encountered by actors during the activities or course of cassava processing.

Method of Data Analysis. The following statistical and econometrics tools were used to achieve specific and broad objectives:

- Descriptive Statistics;

- Gross Margin Analysis;

- Financial Analysis;

- Probit Model Analysis;

- Five Point Likert Scale;

- Principal Component Analysis.

Descriptive Statistics. This involves or encompasses the use of mean, frequency distributions, percentages. Descriptive statistics was used to have a summary statistics of data obtained from the field. This was used to achieve specific objectives one (i), and five (v) which identifies the socio-economic characteristics of actors of cassava processors and constraints or problems facing actors of cassava processing.

Gross Margin Analysis. Gross Margin Analysis is defined as the difference between the observed gross farm income (GFI) and total variable cost (TVC) (Olukosi and Erhabor, 2005). It was used to determine the potentials profitability of cassava processing. The tools were used to achieve specific objective two (ii).

Gross margin model (GM) is expressed as follows:

$G M=T R-T V C$ 
Where: $\mathrm{GM}=$ Gross Margin ( $($ ), TR = Total Value of Output or Total Revenue from cassava

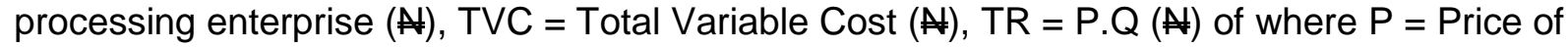
cassava processing in Naira per Kilogram, $Q=$ Output of cassava processing in Kilogram.

Net Income (NI) is stated thus:

$N I=\sum_{i=1}^{n} P_{1} Y_{i}-\sum_{j=i}^{m} P_{j} X_{j}-\sum_{k=1}^{k} G K$

Where: $\mathrm{NI}=$ Net Income (Naira Per annum), $\mathrm{P}_{\mathrm{i}}=$ Unit Price of Product (Naira/Unit), $\mathrm{P}_{\mathrm{j}}=$ Price per Unit Variable Input (Naira/Unit), $G K=$ Cost of all Fixed Inputs (where $k=1,2,3, \ldots k$ fixed input), $\Sigma=$ Summation or Addition signs.

This was used to achieve part of specific objective two (ii)

Financial Analysis. Gross Margin Ratio (GMR) following Ben-Chendo (2015) was used to determine the profitability of cassava processing. This was used to achieve part of specific objective two (ii):

$$
\text { Gross Margin Ratio }=\frac{\text { Gross Margin }}{\text { Total Revenue }}
$$

In order to evaluate the strength and financial positions of cassava processing enterprises, operating ratio and rate of return per naira invested were considered. An operating ratio (OR) according to Olukosi and Erhabor (2005) is stated thus:

$$
O R=\frac{T V C}{G I}
$$

Where: OR = Operating Ratio (Units), TVC= Total Variable Cost (Naira), GI= Gross Income (Naira).

An Operating Ratio (OR) that is less than one (1) implies that the total revenue obtained from cassava processing was able to pay for the cost of variable inputs used in the enterprise (Olukosi and Erhabor, 2005). The rate of return per naira invested (RORI) in cassava processing is stated thus:

$$
R O R I=\frac{N I}{T C}
$$

Where: RORI = Rate of Return per Naira Invested (Units), $\mathrm{NI}=$ Net Income from Cassava Processing (Naira), TC = Total Cost (Naira). The financial analysis was used to achieve part of specific objective two (ii).

Probit Model Analysis. A Probit model following Alabi et al (2013) was used. Probit model is stated as:

$$
Z_{i}=\beta_{0}+\beta_{1} X_{1}+\beta_{2} X_{2}+\beta_{3} X_{3}+\beta_{4} X_{4}+\beta_{5} X_{5}+\beta_{6} X_{6}+\beta_{7} X_{7}+\beta_{8} X_{8}+\beta_{9} X_{9}+U_{i}
$$

Where:

$Z_{i}=$ Output of Cassava Processing (1, if Output > Mean Score; 0, Otherwise),

$\mathrm{i}=$ Number of Independent Variables,

$\beta_{0}=$ Constant Term,

$\beta_{1}-\beta_{8}=$ Regression Coefficients,

$X_{1}=$ Gender (1, Male; 0, Otherwise),

$X_{2}=$ Age (Years),

$X_{3}=$ Marital Status (1, Married; 0, Otherwise)

$X_{4}=$ Experience in Cassava Processing (Years),

$X_{5}=$ Level of Education (0, Non-Formal; 1, Primary; 2, Secondary; 3, Tertiary), 
$X_{6}=$ Grating Asset Machine (1, Ownership; 0, Otherwise),

$X_{7}=$ Access to Credit (1, Access; 0, Otherwise),

$X_{8}=$ Contact with Extension Agent (1, Contact; 0, Otherwise),

$X_{9}=$ Distant to Nearby Market (Kilometer),

$\mathrm{U}_{\mathrm{i}}=$ Error Term.

This was used to achieve specific objective four (iv).

Five Point Likert- Scale. To determine the mean rating of technologies used and ascertain the perceptions of actors in cassava processing, problems and constraints faced by cassava processors, Five-Point Likert- scale was used. To determine the mean rating of technologies used and ascertain actors of cassava processors perceptions, the response options and values assigned were as follows: strongly agree $=5$; agree $=4$; undecided $=3$, disagree $=2$, and strongly disagree $=1$. These values were added and divided by 5 to obtain 3.0 , which was observed and regarded as the mean. Perceptions, or problems with mean scores (MS) greater than or equal to 3.0 was regarded as "Significant" while perceptions, or problems with mean responses lower than 3.0 was regarded as "Non-Significant". The mean scores for this study were calculated using the formula below:

$$
M S=\frac{\sum[R P \times O]}{\sum F}
$$

Where: $\mathrm{MS}=$ Mean Score (Units), $\mathrm{RP}=$ Rating Point (Units), $\mathrm{O}=$ Observations (Units), $\Sigma F=$ Total Number of Sampled Respondents (Units).

This was used to achieve part of specific objectives one (1) and five (v).

Principal Component Analysis (PCA). The perceived constraints or problems faced by actors of cassava processing were analyzed using principal component analysis (PCA). The Model of Principal Component (PCA) is stated thus:

$$
\begin{gathered}
x=x_{1}, x_{2}, x_{3}, \ldots, x_{p} \\
\propto_{k}=\propto_{1 k 1}, \propto_{2}{ }_{K} \propto_{3} k, \ldots, \propto p k \\
\propto_{K}^{T} x=\sum_{j=1}^{p} \propto_{K j X j} \\
\operatorname{Var}=\left[\propto_{K}^{T} X\right] \text { is Maximum }
\end{gathered}
$$

Subject to:

$$
\begin{gathered}
\propto_{K}^{T} \propto_{K}=1 \\
\operatorname{Cov}=\left[\propto_{1}^{T} \propto-\propto_{2}^{T} \propto\right]=0
\end{gathered}
$$

The Variance of each of the Principal Component is:

$$
\begin{gathered}
\operatorname{Var}\left[\propto_{k} X\right]=\lambda_{k} \\
S=\frac{1}{n-1}(X-\bar{X})(X-\bar{X})^{T} \\
S_{i}=\frac{1}{n-1} \sum_{i=1}^{n}\left(X_{i}-\bar{X}_{i}\right)\left(X_{I}-\bar{X}_{i}\right)
\end{gathered}
$$

Where: $\mathrm{X}=$ vector of 'P' Random Variables, $\alpha_{k}=$ Vector of 'P' Constraints, $\lambda_{k}=$ Eigen Value, $\mathrm{T}=$ Transpose, $\mathrm{S}=$ Sample Covariance Matrix, This was used to achieve specific objective five (v).

\section{RESULTS AND DISCUSSION}

Socio-Economic Characteristics of Actors in Cassava Processing Activities. Table 1 shows the socio-economic characteristics observed for actors or cassava processors. About 
$76 \%$ of actors were female, while $24 \%$ of actors were male. The male actors were mainly involves in milling and grinding activities of cassava processing. Female were seen to dominate the activities of cassava processing, it is belief by rural communities that activities involves in cassava processing were purely for women folk. This result agrees or is in line with findings of lbekwe et al (2012).Also, 82\% of actors were less than 50 years in age. The activities involves in cassava processing can be observed to enjoy the patronage of young, and economically active and energetic people, they can withstand the stress and labour requirements involved in activities of cassava processing. This result agrees or in consonance with findings of Alabi and Alabi (2012), and Odebode (2008). Furthermore, 48\% of actors were married, while $16 \%$ of actors of cassava processing were single. This result agrees or is in line with findings of lbekwe et al (2012). The actors were literate, $82 \%$ of them had formal education. The well-educated actors will be able to exchange new ideas among themselves, adopt new innovations and new technologies. This result agrees or is in line with Alabi and Ibrahim (2018), and Oluwasola (2010). The mean household size for actors of cassava processing was nine (9) people. This agrees or is in line with findings of Alabi and Ajooku (2012), Abah (2011), Oyale (2008). The actors had considerable experiences in cassava processing. The mean years of experiences in cassava processing by actors were 20 years. This result agrees or is in consonance with findings of Alabi and Ajooku (2012).

Table 1 - Socio-Economic Characteristics of Actors in Cassava Processing

\begin{tabular}{|c|c|c|c|}
\hline Variable & Frequency & Percentage & Mean \\
\hline $\begin{array}{l}\text { Sex } \\
\text { Male } \\
\text { Female } \\
\text { Age (Years) } \\
21-30 \\
31-40 \\
41-50 \\
51-60 \\
\text { Marital Status } \\
\text { Married } \\
\text { Single } \\
\text { Widowed } \\
\text { Divorce } \\
\text { Level of } \\
\text { Education } \\
\text { Primary } \\
\text { Secondary } \\
\text { Tertiary } \\
\text { Non-Formal } \\
\text { Household Size } \\
\text { (Units) } \\
1-5 \\
6-10 \\
11-15 \\
16-20 \\
\text { Experiences in } \\
\text { Processing (Years) } \\
1-10 \\
11-20 \\
21-30 \\
31-40 \\
\text { Total }\end{array}$ & $\begin{array}{l}24 \\
76 \\
10 \\
34 \\
48 \\
08 \\
48 \\
16 \\
27 \\
09 \\
\\
44 \\
26 \\
12 \\
18 \\
\\
14 \\
55 \\
26 \\
05\end{array}$ & $\begin{array}{l}24.00 \\
76.00 \\
10.00 \\
34.00 \\
48.00 \\
08.00 \\
48.00 \\
16.00 \\
27.00 \\
09.00 \\
\\
44.00 \\
26.00 \\
12.00 \\
18.00 \\
\\
14.00 \\
55.00 \\
26.00 \\
05.00 \\
\\
\\
12.00 \\
35.00 \\
47.00 \\
06.00 \\
100.00\end{array}$ & 41.0 \\
\hline
\end{tabular}

Source: Field Survey (2019), Computed Using STATA Version14.

Costs and Returns Analysis of Processing Cassava into Chips and Garri. The costs estimated as well as returns in the activities of processing cassava products into garri and chips were presented in Tables 2 and 3.The costs considered in activities involved in processing cassava into garri as presented in Table 2 were, cost used in purchasing fresh 
cassava tubers, cost involved in hired labour, cost used to purchase firewood, cost used for grinding cassava. The total variable cost was estimated at 33, 900 Naira. The total cost was calculated to be 38,400 Naira. The cost used for hired labour accounted for $18.22 \%$ of total cost, while the cost used to purchase fresh tuber accounted for $62,5 \%$ of the total cost involved in activities of processing cassava into garri by actors. The rate of return on investment and operating ratio involved in activities of cassava processing into garri were 1.09 and 0.72 respectively. The gross margin ratio was 0.57 . This means that for every one naira invested in garri processing enterprises, 57kobo covered taxes, expenses, depreciation and profits. This result agrees or is in line with findings of Alabi and Ajooku (2012), and Afolabi (2009). The net returns was calculated to be 42,000 Naira, this means cassava processing activities into garri by actors was profitable.

Table 2 - Costs and Returns Involved in Activities of Cassava Products Processed into Garri by Actors

\begin{tabular}{|c|c|c|c|}
\hline \multicolumn{2}{|l|}{ Items } & Value $(\mathbb{N})$ & Percentages \\
\hline \multicolumn{4}{|c|}{ (a) $\quad$ Variable Cost (VC) } \\
\hline \multicolumn{2}{|c|}{ Fresh Tubers of Cassava } & 24,000 & 62.5 \\
\hline \multicolumn{2}{|c|}{ Cost of Labour } & 7,000 & 18.22 \\
\hline \multicolumn{2}{|c|}{ Grinding Cost } & 1,500 & 3.91 \\
\hline \multicolumn{2}{|c|}{ Firewood Cost } & 1,400 & 3.65 \\
\hline \multicolumn{2}{|c|}{ Total Variable Cost } & 33,900 & 88.28 \\
\hline \multicolumn{4}{|c|}{ (b) Depreciated Values (Fixed Cost) } \\
\hline \multicolumn{2}{|l|}{ Store } & 700 & 1.82 \\
\hline \multicolumn{2}{|c|}{ Frying Pan } & 400 & 1.04 \\
\hline \multicolumn{2}{|c|}{ Washing Basin } & 450 & 1.17 \\
\hline \multicolumn{2}{|l|}{ Knife } & 250 & 0.65 \\
\hline \multirow{2}{*}{\multicolumn{2}{|c|}{$\begin{array}{l}\text { Screw Jack } \\
\text { Measuring Bowl }\end{array}$}} & 1,700 & 4.43 \\
\hline & g Bowl & 700 & 1.82 \\
\hline \multicolumn{2}{|l|}{ Sieve } & 300 & 0.78 \\
\hline & Total Fixed Cost (TFC) & 4,500 & 11.72 \\
\hline (d) & Total Cost (TC) & 38,400 & \\
\hline (e) & Total Revenue (TR) & 80,400 & \\
\hline (f) & Gross Margin (GM) & 46,500 & \\
\hline (g) & Net Returns & 42,000 & \\
\hline & Rate of Returns on Investment & & \\
\hline (RORI) & & 1.09 & \\
\hline & Operating Ratio (OR) & 0.72 & \\
\hline & Gross Margin Ratio (GMR) & 0.57 & \\
\hline & & & 100.00 \\
\hline
\end{tabular}

Source: Field Survey (2019), Computed Using STATA Version 14.

The costs involved in processing a tonne of cassava into chips were cost involved in purchasing the fresh cassava tubers, cost of transportation, and cost used to pay for hired labour (Table 3). The total variable cost was estimated at 24,050 Naira, the total cost was calculated to be 26, 950 Naira. The cost used to buy fresh cassava tuber accounted for $72.35 \%$ of the total cost, while cost incurred in transportation accounted for $10.01 \%$ of total cost in cassava chips enterprise. The rate of return on investment and operating ratios were calculated to be 0.76 and 0.51 respectively. The gross margin ratio was calculated to be 0.49 . This means that for every one Naira invested in cassava processing activities into chips by actors, 49 kobo covered taxes, expenses, profits, and depreciation. The net returns was 20,550 Naira, this means that cassava processing activities by actors into chips was profitable.

Mean Statistical Rating of Traditional and Modern or Improved Technologies Used by Actors. The mean statistical ratings using five point Likert scales were presented in Tables 4 and 5. Three (3) out of seven (7) traditional technologies as presented in Table 4 had mean values between 3.10 and 3.51. These mean values were greater than the mean value of 3.0 for five point Likert scale. This means the traditional technologies that were significant in cassava processing activities by actors were, using bag (jute) for bagging products (3.10), hand grating for peeling cassava (3.24), and calabash bowl for washing cassava products (3.51). This result agrees with FAO (1999) who identified some main traditional technologies used in cassava processing activities by actors to be knife for peeling cassava, cutlasses for chopping cassava, heavy stones for dewatering, and sun drying of cassava products. 
Table 3 - Costs and Returns Involved in Activities of Cassava Products Processed into Chips by Actors

\begin{tabular}{|c|c|c|c|}
\hline Items & & Value $(\mathrm{A})$ & Percentages \\
\hline (a) & Variable Cost (VC) & & \\
\hline Fresh Tu & ubers of Cassava Cost & 19,500 & 72.36 \\
\hline Cost of $\mathrm{L}$ & _abour for Peeling/Chopping Cassava & 1,850 & 06.87 \\
\hline Cost of $\mathrm{T}$ & Transportation & & \\
\hline Total Var & riable Cost & 2,700 & 10.01 \\
\hline (b) & Depreciated Values (Fixed Cost) & 24,050 & 89.24 \\
\hline Ferments & ation Bowl & 900 & 3.34 \\
\hline Knife & & 850 & 3.15 \\
\hline Measurin & ng Bowl & 270 & 1.00 \\
\hline & Total Fixed Cost (TFC) & 880 & 3.27 \\
\hline & Total Cost (TC) & 2,900 & 10.76 \\
\hline & Total Revenue (TR) & 26,950 & \\
\hline & Gross Margin (GM) & 47,500 & \\
\hline & Net Returns & 23,450 & \\
\hline (h) & Rate of Returns on Investment & 20,550 & \\
\hline & Operating Ratio (OR) & 0.762 & \\
\hline & Gross Margin Ratio (GMR) & 0.51 & \\
\hline & & 0.49 & \\
\hline & & & 100.00 \\
\hline
\end{tabular}

Source: Field Survey (2019), Computed Using STATA Version 14.

Table 4 - Mean Statistical Rating of Traditional Technologies Used by Actors

\begin{tabular}{|l|l|}
\hline \multicolumn{1}{|c|}{ Traditional Technologies } & \multicolumn{1}{c|}{ Mean SD Decision } \\
\hline Using Local Bag (Jute) for Bagging of Products & 3.100 .722 Significant \\
Sun Drying or Using Road Side Platform & 2.130 .632 Non-Significant \\
Using Cutlass or Kitchen Knife for Chopping Cassava & 1.671 .912 Non-Significant \\
Sieving Using Woven Baskets & 1.511 .821 Non-Significant \\
Heavy Stones Used for Dewatering & 2.161 .417 Non-Significant \\
Hand Grating for Peeling Cassava & 3.241 .617 Significant \\
Calabash Bowl Used for Washing & 3.511 .571 Significant \\
\hline
\end{tabular}

Source: Field Survey (2019), Computed Using STATA Version 14.

The improved or modern technologies used by actors in cassava processing activities were presented in Table 5. Nine (9) technologies were used, six (6) had mean values greater than 3.0 using five point Likert scale rating. The six (6) improved or modern technologies used had mean values between 3.62 and 4.12. The significant improved or modern technologies were mechanical pulverizer (4.12), vibrating sieve for sieving cassava products (3.63), solar drier used for drying cassava products (3.71), kiln or oven used for drying cassava products (3.82), motorized grater for grating cassava products (3.92), and mechanical peeler (4.12). This result agrees or is in line with findings of Alabi, Efunnuga, Omodona, and Lawal (2009), Davies et al (2008)

Table 5 - Mean Statistical Rating of Improved or Modern Technologies Used by Actors

\begin{tabular}{|l|l|}
\hline \multicolumn{1}{|c|}{ Traditional Technologies } & \multicolumn{1}{c|}{ Mean SD Decision } \\
\hline Mechanized Pulverizer Used for Chopping Cassava & 4.121 .96 Significant \\
Screw Jack Used for Dewatering & 2.13 1.53 Not-Significant \\
Hydraulic Jack for Dewatering & 2.71 1.63 Not-Significant \\
Vibrating Sieve for Sieving Products & 3.631 .83 Significant \\
Solar Drier Used for Drying Products & 3.711 .93 Significant \\
Kiln or Oven Dryer of Products & 3.821 .89 Significant \\
Motorized Grater for Grating Cassava & 3.921 .93 Significant \\
Mechanical Peeler & 4.121 .73 Significant \\
Aluminium Tank Used in Washing Products & 2.141 .63 Not-Significant \\
\hline
\end{tabular}

Source: Field Survey (2019), Computed Using STATA Version 14. 
Factors influencing Output of Cassava Processing by Actors. Factors affecting or influencing output of cassava processing were presented in Table 6. Nine (9) explanatory or predictor or regressor or exogenous variables were examined in the Probit model. The variables were, gender, age, marital status, experience in cassava processing, level of education, grating asset machine, access to credit, contact with extension agent, and distant to nearby market. Five (5) exogenous variables were statistically significant in influencing output of cassava processing, the five $(5)$ predictor variables were, gender $(P<0.05)$, marital status $(P<0.01)$, experience in cassava processing $(P<0.01)$, level of education $(P<0.01)$, contact with extension agents $(P<0.01)$ and distant to nearby market $(P<0.01)$. A unit (1) increase in level of actors' education will lead to 0.1686 marginal increases in output of cassava processing. In addition, a unit (1) increase in contact with extension officers by actors' will lead to 0.2343 marginal increases in output of cassava processing. The Maximum Likelihood Estimates shows that the Log Likelihood was -101.81321, Chi square values were 69.68 and were statistically significant at $1 \%$ probability level. The Pseudo $R$ Square value was 0.7403 . This means that $74.03 \%$ of the variations in response or endogenous variable included in the Probit model were explained by the exogenous variables included in the regression model. The fitted equation for the Probit regression model is stated as:

$$
Z=0.2543+0.041 X_{1}+0.4171 X_{2}+0.3471 X_{3}+0.7745 X_{4}+0.1964 X_{5}+0.388 X_{6}+0.1415 X_{7}+0.3751 X_{8}+0.0356 X_{9}
$$

This result agrees or is in line with findings of Alabi (2012), Alabi and Alabi (2002) and Alabi, Coker, Adeola, and Maduekwe (2010).

Table 6 - Factors Influencing Output of Cassava Processing

\begin{tabular}{lllll}
\hline Variables & Coefficient & Standard Error & Z-Score & Marginal Effect \\
\hline Gender $\left(\mathrm{X}_{1}\right)$ & 0.0415228 & 0.0153223 & $2.80^{\star *}$ & 0.0196 \\
Age $\left(\mathrm{X}_{2}\right)$ & 0.4171633 & 0.3373271 & 1.21 & 0.1136 \\
Marital Status $\left(\mathrm{X}_{3}\right)$ & 0.3471527 & 0.070065 & $7.4^{\star * *}$ & 0.0419 \\
Experience in Cassava & 0.7745443 & 0.358186 & $5.16^{\star * *}$ & 0.1461 \\
Processing $\left(\mathrm{X}_{4}\right)$ & & & & \\
Level of Education $\left(\mathrm{X}_{5}\right)$ & 0.1964578 & 0.3452589 & $4.28^{\star \star *}$ & 0.1686 \\
Grating Asset Machine $\left(\mathrm{X}_{6}\right)$ & 0.388006 & 0.45058 & 0.75 & 0.1302 \\
Access to Credit $\left(\mathrm{X}_{7}\right)$ & 0.141572 & 0.431442 & 0.211 & 0.1013 \\
Contact with Extension & 0.37510 & 0.67543 & $3.73^{\star *}$ & 0.2343 \\
Agents $\left(\mathrm{X}_{8}\right)$ & & & & \\
Distant to Nearby Market $\left(\mathrm{X}_{9}\right)$ & 0.03560 & 0.5768 & $4.34^{\star \star *}$ & 0.1127 \\
Constant & 0.2543 & 0.6732 & $2.63^{\star *}$ & \\
\hline
\end{tabular}

$\mathrm{Chi}^{2}=69.68^{* \star *}$

Pseudo $R^{2}=0.7403$

Log likelihood $=-101.81321$

${ }^{* *}$ - Significant at Probability $<0.05,{ }^{* * *}$ - Significant at Probability $<0.01$.

Source: Field Survey (2019), Computed Using STATA Version 14.

Constraints of Problems Facing Actors in Activities of Cassava Processing. The constraints or problems facing actors in activities of processing cassava into garri and chips were presented in Table 7. Principal Component Analysis was used in the analysis. Principal Component Analysis is a statistical technique or applications that can reduce data with many variables that were uncorrelated into smaller or few variables. The numbers of variables retained from the principal component were eleven (11) based on Eigen value greater than one (1).The retained components observed in the analysis explained $98.61 \%$ of the variations of the components included in the model. The Kaiser-Meyer-Olkin (KMO) was 0.74 , and this measure the sampling adequacy, and the Bartlett test of sphericity of 2058.002 and was significant at $1 \%$ level of probability. High cost of processing equipment with Eigen value of 3.58621 was ranked $1^{\text {st }}$ in the order of importance based on the perceptions of actors in cassava processing activities. High cost of transportation and problem of labour shortages with Eigen values of 2.86314 and 2.59432 were ranked $2^{\text {nd }}$ and $3^{\text {rd }}$ respectively based on the perceptions of actors in cassava processing activities. 
Table 7 - Results of the Principal Component Analysis of Constraints or Problems Facing Actors in Cassava Processing Activities

\begin{tabular}{|c|c|c|c|c|}
\hline Constraints & Eigen Value & Difference & Proportion & Cumulative \\
\hline High Cost of Processing Inputs & 3.58621 & 0.4951 & 0.1127 & 0.1127 \\
\hline High Cost of Transportation & 2.86314 & 1.2776 & 0.2423 & 0.3550 \\
\hline Problem of Labour Shortage & 2.59432 & 0.364165 & 0.1667 & 0.5277 \\
\hline Lack of Credit Facilities & 1.38328 & 0.22231 & 0.1088 & 0.6365 \\
\hline Poor Road Network & 1.35174 & 0.24072 & 0.1266 & 0.7631 \\
\hline Lack of Access to Market & 1.21764 & 0.12876 & 0.0376 & 0.8007 \\
\hline High Perishability of Cassava & 1.21277 & 0.3421 & 0.0976 & 0.8983 \\
\hline Lack of Space for Sundry of Cassava & 1.3478 & 0.4581 & 0.0543 & 0.9526 \\
\hline Fluctuations in Prices & 1.2198 & 0.6249 & 0.0123 & 0.9643 \\
\hline Increased Taxes on Products & 1.2021 & 0.5389 & 0.0101 & 0.9750 \\
\hline Electricity Problem & 1.2004 & 0.5211 & 0.0111 & 0.9861 \\
\hline $\begin{array}{l}\text { Bartlett Test of Sphericity } \\
\text { KMO } 0.740 \\
\text { Chi-Square } 2058.002^{* * *} \\
\text { Rho } 1.0000\end{array}$ & & & & \\
\hline
\end{tabular}

Source: Field Survey (2019) using STATA Version 14.

\section{CONCLUSION AND RECOMMENDATIONS}

The results observed from the analysis and presented confirmed that cassava processing by actors was profitable. The net returns of garri enterprise were 42,000 Naira. The net returns for cassava chips enterprise were 20,550 Naira. The actors in the activities of cassava processing used both traditional and improved or modern technologies. The traditional technologies used include amongst others; local bag (jute) for bagging, hand grating for peeling cassava, calabash bowl for washing, these traditional technologies were statistically significant among the others used by actors. The improved or modern technologies used by actors include amongst others: mechanized pulverizer for chopping cassava, vibrating sieve for sieving the cassava products, solar drier for drying cassava products, kiln or oven for drying cassava products, motorized garter for grating cassava, and mechanical peeler. These improved or modern technologies were statistically significant .The gross margin ratio of 0.49 for garri enterprise means that for every one (1) Naira invested in cassava chips enterprise by actors 45 kobo covered taxes, expenses, profits, and depreciation. The gross margin ratio of 0.57 cassava chips enterprise means that for every one (1) Naira invested in cassava chips enterprise, 57 kobo covered taxes, expenses, depreciation and profits. Gender, marital status, experience in cassava processing, level of education, contact with extension agents, and distant to nearby market were statistical and significant variables influencing output of cassava processing by actors. The major problems or constraints facing actors in cassava processing include: high cost of inputs, high transportation costs, problems of labour shortage, lack of credit facilities, poor road infrastructures, and lack of access to market. The retained constraints or problems explained $98.61 \%$ of the variables included in the model.

The government should employ extension agents in the area; they will assist in disseminations of research findings including modern technologies to actors of cassava processing. 
Government should formulate policies that will stabilize prices of agricultural commodities to encourage actors in their various agricultural enterprises.

Actors should be encouraging to from cooperatives organizations, this will enable actors to access credit and modern processing inputs.

Electricity should be made regular; this is an infrastructure that can increase cassava processing output.

\section{REFERENCES}

1. Abah, E.O (2011). Economic of Organic Solid Waste Utilization by Urban Smallscale Tomato Farmers in Federal Capital Territory, Abuja, Nigeria. An MSc Thesis Submitted to the Department of Agricultural Economics, University of Nigeria, Nsukka.

2. Afolabi, J.A (2009). An Assessment of Garri Marketing in South West Nigeria. Journal of Social Science 21 (10): 33-38

3. Alabi, O.O; Coker, A.A.A; Idegbesor, M.E (2013).Net Farm Income Analysis of Maize Production in Gwagwalada Area Council of Federal Capital Territory, Nigeria, Journal of Agriculture, Forestry and Social Sciences(JOAFSS), 11(1):166-182

4. Alabi, O.O and Alabi, O.A (2002) Economics of Cassava Production In Kogi State: A Case Study of Yagba East Local Government Area, Savannah Journal of Science and Agriculture 1(1):105-110

5. Alabi,O.O; Coker, A.A.A; Idegbesor, M.E (2013).Net Farm Income Analysis of Maize Production in Gwagwalada Area Council of Federal Capital Territory, Nigeria, Journal of Agriculture, Forestry and Social Sciences(JOAFSS), 11(1):166-182

6. Alabi, O.O; Efunnuga,C.T; Omodona, S and Lawal, A.F (2009). Factors Influencing Gross Income from Cassava Processing In Ikenne Local Government Area of Ogun State, International Journal of Sustainable Development (IJSD) 6(2):59-65

7. Alabi, O.O. and Ajooku,H.A (2012).Socio-Economic Factors Influencing Cassava Production in Kuje and Abaji Area Councils of Federal Capital Territory, Abuja, Nigeria, Journal of Agriculture, Forestry and Social Sciences (JOAFSS),10(2):73-84.

8. Alabi, O.O.; Coker, A.A; Adeola, S.S and Maduekwe, I (2010). Technical Efficiency in Sesame Production in Nassarawa Doma Local Government Area of Nassarawa State, Nigeria: An Application of Stochastic Frontier Model, International Journal of Agriculture and Rural Development 1(2):115-121.

9. Alabi, O.O.(2012).Profitability Analysis of Maize and Sorghum Production Among Cooperative Societies' Farmers in Gwagwalada and Kwali Area Councils of FCT, Abuja, Nigeria, Benin International Journal of Agricultural Economics and Extension Services 2(1):8 - 14 .

10. Alabi, O.O. and Ibrahim, A (2018). Economics of Maize (Zea mays) Production in Igabi Local Government of Kaduna State, Nigeria. Journal of Agricultural Faculty of Gaziosmanpasa University (JAFAG) .Volume 35 (3): 248-257.

11. Ben-Chendo, G.N, N. Lawal, M.N. Osuji, I.I. Osugiri, and B.O. Ibeagwa, (2015). Cost and Returns of Paddy Rice Production in Kaduna State of Nigeria. International Journal of Agricultural Marketing 2(5):084-089.

12. CBN (2019). Central Bank of Nigeria. Welcome Address Presented by Central Bank Governor Godwin I. Emefiele (CON) at the meeting with State Governors of Cassava Producing States and Signing of the Memorandum of Understanding between Nigeria Cassava Growers Association and Large Scale Cassava Processors, Abuja, November 21, 2019.

13. Davies, R.A, Olatunji,M.O and Burahai, W (2008). A Survey of Cassava Processing Machinery in Oyo State, Owrld Journal of Agricultural Science 4 (3): 337 - 340

14. FAO (1999, 2019). Food and Agricultural Organization, Statistical Database Ibekwe, U.C, Chikeizie, C Obasi, P.C, Eze, C.C and Henri-Ukoha, A (2012). Profitability of Garri Processing in Owerri North Local Government Area of Imo State. ARPN Journal of Science and Technology 2 (4): $340-343$ 
15. Knipscheer, H; Ezedinma, C; Kormawa, P; Asumugha, G, Makinde, K; Okechukwu, R, and A Dixon (2007). Opportunities in the Industrial Cassava Market in Nigeria. International Institute for Tropical Agriculture (IITA).

16. Nang'ayo, F; omanya, G; Bokanga, M; Odera, M; Muchiri, N; Ali, Z; and Werehire, P (2005). A Strategy for Industrialization of Cassava in Africa: Proceedings of Small Groups Meeting, 14-18 November 2005, Ibadan, Nigeria.

17. Odebode, S.O (2008).Appropriate Technology for Cassava Processing in Nigeria: User's Point of View. Journal of International Women's Studies 9 (3): 269-283.

18. Oluwasola, O. (2010). Stimulating Rural Employment and Income for Cassava (Manihot species) Processing Farming Households in Oyo State, Nigeria through Policy Initiatives. Journal of Development and Agricultural Economics 2 (2): 18 - 25

19. Olukosi, J.O. and Erhabor, P.O. (2005). Introduction to Farm Management Economics: Principles and Applications. Agitab Publishers Limited, Zaria, Kaduna, Nigeria. pp. 77-83. 